Sectarianization, Identity, and How Terrorism Prevails:

The Case of Al-Qaeda in the Islamic Maghreb (AQIM)

in the Sahel Region of Africa

\section{Adzraa Shaffa Andira}

${ }^{\prime}$ University College Maastricht, Maastricht University, The Netherlands a.shaffaandira@student.maastrichtuniversity.nl

\section{Sentris}

SENTRIS ACADEMIC JOURNAL

UNIVERSITAS KATOLIK PARAHYANGAN

BANDUNG

ISSN 0216-5031

VOLUME 2 No. 2

Hal. 166 - 176

https://doi.org/10.26593/sentris.v2i2.5257.166-176 


\title{
Sectarianization, Identity, and How Terrorism Prevails: The Case of Al-Qaeda in the Islamic Maghreb (AQIM) in the Sahel Region of Africa
}

\author{
Adzraa Shaffa Andira ${ }^{1}$ \\ ${ }^{1}$ University College Maastricht, Maastricht University, The Netherlands, \\ a.shaffaandira@student.maastrichtuniversity.nl
}

\begin{abstract}
Various patterns have emerged as a result of globalization when it comes to controlling the kind of threats that a country may face, particularly non-traditional ones. One of them is terrorism, concentrated in specific places of the world, with North and Sub-Saharan Africa dominating for a variety of reasons. While there are other operational areas contested by various terrorist groups, the Sahel is one of the most well-known, with Al-Qaeda in the Islamic Maghreb (AQIM) being one of the most infamous terrorist groups. Legacies of weak and corrupt governments and institutions, unenforced border security, historical disadvantages, and crippled economies may serve as catalysts for such groups' growing influence, but this paper would argue that the use of sectarianism as a tool of identity mobilization is one of the reasons for AQIM's prevalence as a terrorist group.
\end{abstract}

Keywords: sectarianization, AQIM, terrorism, identity mobilization, identity.

\section{Introduction}

Through globalization, there have been various trends growing when it comes to seeing the form of threats a country might stumble upon, especially the non-traditional ones. One of them being terrorism, occuring in various gaps in the world system, challenging the national and global authorities. ${ }^{1}$ Throughout 2019, approximately 8,302 attacks occurred worldwide, killing more than 21 thousand people annually throughout the past 10 years and responsible for over $0.05 \%$ of casualties globally. ${ }^{23}$ Furthermore, terrorism also tend to be concentrated in certain parts of the world, which was dominated by North and Sub-saharan Africa for numerous reasons. ${ }^{4}$ While there are many operational areas contested by various terrorist groups, one of the infamous one being the Sahel. The Sahel is a part of Africa that expands within Senegal and ends in Sudan, which also includes Mali, Mauritania, Burkina Faso, Niger, Nigeria, and Chad. ${ }^{5}$ Most highlight how the Sahel serves as a transitional area between the 'deserts and savannas' of Africa. ${ }^{6}$ However, its interconnected borders and strategic positions apparently serve as fertile land for crises to spur.

For the past decade, the Sahel has been developing into a fire pit of conflict between actors within various levels, namely countries --represented mostly through national army forces--, local armed insurgency groups, terrorist militias, and international affiliates through peacekeeping forces. ${ }^{7}$ While there are other terrorist groups active in the region, the al-Qaeda-linked groups have been the

\footnotetext{
${ }^{1}$ Albert J. Bergensen and Omar Lizardo, "International Terrorism and the World-System," Sociological Theory 22, no. 1 (2004): pp. 38-52, 40.

"Terrorism: Number of Attacks Worldwide 2019," Statista, June 28, 2021, https://www.statista.com/statistics/202864/number-of-terrorist-attacks-worldwide/.

${ }^{3}$ Hannah Ritchie et al., "Terrorism," Our World in Data, July 28, 2013, https://ourworldindata.org/terrorism.

4 "Terrorist Attacks by Region," Our World in Data, accessed July 5, 2021, https://ourworldindata.org/grapher/terroristattacks-by-region.

5 "The Sahel: Land of Opportunities | Africa Renewal," United Nations (United Nations), accessed July 5, 2021, https://www.un.org/africarenewal/sahel.

${ }^{6}$ Ibid.

${ }^{7}$ Al Jazeera, "The Sahel: Key Things to Know as Security Crisis Spirals," Al Jazeera (Al Jazeera, February 27, 2020), https://www.aljazeera.com/features/2020/2/27/the-sahel-key-things-to-know-as-security-crisis-spirals.
} 
two main protagonists behind increasing attacks in recent years. ${ }^{8}$ One of them being Al-Qaeda in Islamic Maghreb (AQIM). According to the United Nations, attacks in Burkina Faso, Mali, and Niger have grown fivefold since 2016, with more than 4,000 deaths reported last year in the three hardest-hit nations' border zones. ${ }^{9}$ Since 2015, this organization has stated that they account for attacks in the aforementioned countries, and has also cooperated with local groups in the region to extend their influence and effectivity of their attacks. ${ }^{10}$ This paper would discuss the influential presence of AQIM in the Sahel area. While the legacies of weak and corrupt governments and institutions, unenforced border security, unequipped and improperly trained forces, historical disadvantages, and crippled economies might serve as the catalyst of the widening influence of such groups, this paper would argue that the utilization of sectarianization as a tool of identity mobilization serves as one of the strongest raisons d'etre upon the prevalence of AQIM as a terrorist group.

\section{Theoretical Framework}

\section{a. Identity}

Identity is defined as certain characteristics relating to self-conception that could affect one's action, depending on whether or not one acknowledges its presence. ${ }^{11}$ Alexander Wendt argues that identities are developed through repetitive interactions that generate common understanding and expectations; which are capable of creating behavioral dispositions and creating interests of political actors. ${ }^{12}$ When the actors have projected their interests, their identities cannot easily be transformed, because the actors have seen the social system as an environment where they can maintain their identities. $^{13}$ However, if the repetitive interactions construct different social systems and environments, then identities may gradually shift, which indicates that leaders play a role in determining a group's interests. ${ }^{14}$ Since identity, as a part of a social element, further constructs societies and groups within a nation; so the practice of actors participating within that system can transform the structure itself. ${ }^{15}$ One of them occurred through the process of identity mobilization.

One core element of identity mobilization is ethnicity. Ethnicity is seen as adaptive towards changes according to the conditions that occur within the social sphere. ${ }^{16}$ Due to this nature, ethnicity serves as an ideal tool for political leaders and their supporters to extend their influence and further their interests through identity mobilization. ${ }^{17}$ Instrumentalists further argue that the driving cause of identity mobilization lies in economic opportunity and political motives. ${ }^{18}$ The economic motive stresses over the domination of resources and wealth between groups separated by certain identities, or if the identity mobilization aims for economical advantage; while the political motive focuses on

\footnotetext{
${ }^{8}$ Ibid.

${ }^{9}$ Ibid.

${ }^{10}$ Javier E. David, "Al Qaeda's Arm in North Africa Has Made around \$100 Million through Ransom and Drug Trading, Study Says,” CNBC (CNBC, December 7, 2017), https://www.cnbc.com/2017/12/06/al-qaedas-arm-in-north-africa-hasmade-100-million-dollars-via-ransom-drug-trade.html.

${ }^{11}$ Daryoush Shahbahrami, "Identity and Power in International Relations," International Journal of Humanities and Cultural Studies, May 2016, pp. 2434-2446, 2439.

12 Maja Zehfuss, "Constructivism and Identity: A Dangerous Liaison," European Journal of International Relations 7, no. 315 (2001): p. 93, https://doi.org/DOI: 10.1177/1354066101007003002, 318.

${ }^{13}$ Ibid, 321.

${ }^{14}$ Ibid, 319.

${ }^{15}$ Shibley Telhami and Michael N. Barnett, Identity and Foreign Policy in the Middle East (Ithaca, NY: Cornell University Press, 2002), 4.

16 Vali R. Nasr, "International Politics, Domestic Imperatives, and Identity Mobilization: Sectarianism in Pakistan, 19791998," Comparative Politics 32, no. 2 (2000), https://doi.org/10.2307/422396, 171-175.

17 Ibid.

${ }^{18}$ Ibid.
} 
how identity mobilization became a socio-political construction where representation is the main important aspect. ${ }^{19}$ Moreover, instrumentalists also state that the communities' political leaders act as the primary actor in identity mobilization, since the steps they adopt in achieving their interests (as well as the interests of their communities) determine the mobilization process itself. ${ }^{20}$

Therefore, one can see that identity mobilization is both a result of political leaders' projection of power and an extension of the community's interests towards economic and political domination. ${ }^{21}$ In this context, the state is viewed as a passive participant in identity mobilization because they are vulnerable to these strong identity groups that serve the interests of substate players who utilize state institutions to fight for dominance. ${ }^{22}$ Furthermore, the deepening of these struggles both indicates and causes the state's weakening and eventual failure and also signals that states with rather narrow capabilities are more prone to undergo identity mobilizations within its society due to the 'gaps' they left unfulfilled in the lives of their people. ${ }^{23}$

\section{b. Sectarianization}

Vali Nasr defines sectarianization as an occurrence where political actors try to go after their goals while incorporating mass mobilization around certain identity markers utilizing pre-existing supporting conditions, such as social disparities, fragile states, and geopolitical contestation. ${ }^{24}$ Such is done by making the group members question the legitimacy of certain aspects in their common identities (which mostly revolves around certain religious interpretations). ${ }^{25}$ Hence, ethnicity also plays an important role in catalyzing sectarianism, since according to David Little, ethnic groups tend to identify themselves in a religious way, and religious identities have become an important factor in constructing a culture, hence the term 'ethno-religious' ${ }^{26}$

Constructivists argue that ethno-religious identity is continuously constructed through social interactions, and while it is important, it does not always cause conflict. ${ }^{27}$ Identity mobilization emerges when a leader addresses gaping social disparities that need changes, hence provoking disputes within the community. ${ }^{28}$ As a result, the state is constrained by "distributed domination," or situations in which neither the state nor societal forces have country-wide dominance. ${ }^{29}$ The fact that the state can employ force at critical moments does not compensate for the state's power constraints and lack of effective dominance. ${ }^{30}$

\footnotetext{
${ }^{19}$ Ibid.

${ }^{20}$ Ibid, Vali R. Nasr, "International Politics, Domestic Imperatives, and Identity Mobilization: Sectarianism in Pakistan, 1979-1998,"171-175.

${ }^{21}$ Ibid.

${ }^{22}$ Ibid, 173

${ }^{23}$ Ibid.

${ }^{24}$ Nader Hashemi and Danny Postel, "Sectarianization: Mapping the New Politics of the Middle East," The Review of Faith \& International Affairs 15, no. 3 (March 2017): pp. 1-13, https://doi.org/10.1080/15570274.2017.1354462, 4.

${ }^{25}$ Ibid, 5 .

${ }^{26}$ Ibid.

${ }^{27}$ Ibid.

${ }^{28}$ Ibid.

${ }^{29}$ Ibid.

${ }^{30}$ Ibid.
} 


\section{Analysis}

\section{a. Al-Qaeda in the Islamic Maghreb (AQIM) and their Shift of Identity}

Al-Qaeda in the Islamic Maghreb is a terrorist group that officially joined Al-Qaeda in 2006, after previously known as the Salafi Group for Preaching and Combat (GSPC). ${ }^{31}$ The group is wellknown in North Africa for kidnapping Westerners for ransom and is involved in the drug, gun, and human trafficking trades. ${ }^{32} \mathrm{AQIM}$ is one of the world's wealthiest terrorist organizations, which attract other groups like Al Mourabitoun, Ansar Dine, and the Macina Liberation Front (MLF) to eventually join AQIM's Sahara branch to form Jamaat Nusrat al-Islam wal Muslimeen (JNIM). ${ }^{33}$

Upon its emergence, there have been several identity mobilizations internally that turned this Algerian insurgency group into Al-Qaeda Maghrebi partner. At first, after the Algerian government nullified Islamic Salvation Front who won the election, armed islamic groups were formed for the purpose of insurgency, which was divided into Groupe Islamique Arme (GIA) and Mouvement Islamique Arme (MIA). ${ }^{34}$ The two groups represent different identities, hence operate towards different objectives. MIA mostly aims to break down the ruling Algerian regime and slain the national armies, while GIA stresses more on mas re-islamisation of the surrounding society through coercive practice of power and the sectarianization practice of takfir (accusing a Muslim as an infidel for even the slightest difference of islamic practices and stances upon certain social issues). ${ }^{35}$ Due to the intense violent propaganda, GIA was able to obtain power over the Algerian population, as well as connecting with external Jihadist group (namely al-Jihad from Egypt), even lobbying Osama bin Laden and obtain funding. ${ }^{36}$ However, by early 1990s, their legitimacy recedes after wide-scale massacres occurred several times, creating public fears and isolating this group from their followers, the Algerian public, as well as the devout Muslim members within the organization. ${ }^{37}$ Since 1992, the GIA executed a violent military campaign of protests against Algerian government, directed at not only national security personnels, but also Algerian civilians who are against the ideology and foreign national members. ${ }^{38}$ After the death threats of those who detached themselves from this organization emerged, in 1998, a group consisting of former members as well as civilians echoed their independence from GIA, calling themselves Groupe Salafiste pour la Prédication et le Combat (GSPC) under the leadership of Hassan Hattab. ${ }^{39}$

Reminiscing that in that era, most devout Muslims realized the practice of killing without strong basis is unacceptable, added with the public distrust emerging from fear of GIA's death threats, GSPC gained members and credibility rapidly. ${ }^{40}$ Hattab later loss of control towards the group due to the intense counterterrorism program initiated by Algerian government, and replaced by Nabil Sahrawi, Ammari Saifi, and Abdelmalek Droukdel who wants to upscale the organization's level of influence and support global moves of jihad, which explains why later Droukdel built a network of

\footnotetext{
31 "Mapping Militants Profile Index," Center for International Security and Cooperation (CISAC), (Stanford University: Freeman Spogli Institute for International Studies, 2016), https://cisac.fsi.stanford.edu/mappingmilitants/profiles.

${ }^{32}$ Ibid.

${ }^{33}$ Ibid.

${ }^{34}$ William Thornberry and Jaclyn Levy, "Al Qaeda in the Islamic Maghreb," Transnational Threats Project: Homeland Security and Counterterrorism Program (Center for Strategic and International Studies, September 2011), https://www.csis.org/analysis/al-qaeda-islamic-maghreb.

${ }^{35}$ Ibid.

${ }^{36}$ Ibid, 2.

${ }^{37}$ Ibid, William Thornberry and Jaclyn Levy, "Al Qaeda in the Islamic Maghreb,” 2.

${ }^{38}$ Ricardo René Larémont, "Al Qaeda in the Islamic Maghreb: Terrorism and Counterterrorism in the Sahel," African

Security 4, no. 4 (2011): pp. 242-268, https://doi.org/10.1080/19392206.2011.628630, 243.

${ }^{39}$ Ibid.

${ }^{40}$ Ibid, Ricardo René Larémont, “Al Qaeda in the Islamic Maghreb: Terrorism and Counterterrorism in the Sahel”, 243.
} 
human and arms smuggling with Al-Qaeda through Abu Mus'ab Al-Zarqawi in Iraq, creating armies of combatants, war strategists, and suicide bombers. ${ }^{41}$ In March 2004, Saifi was captured by a Chadian armed insurgent known as Mouvement pour la Démocratie et la Justice Tchadien during an operation in their areas and was sent back to the Algerian government, where he was sentenced to life imprisonment. ${ }^{42}$ Meanwhile, in the same year, Sahrawi was killed in northern Algeria in a ceasefire with the armies. ${ }^{43}$

Hence, Droukdel became the leader of GSPC overnight. Droukdel's strategic beliefs and philosophy differed from Sahrawi's in that they were more international in nature. Droukdel highlighted the GSPC's goal to engage Islam's "far adversary"--for instance, the US and European states-- and his understanding of jihad was similar to that of Osama bin Laden and Ayman alZawahiri. ${ }^{44}$ Because of their confluence of goals, Droukdel decided to combine his organization to $\mathrm{Al}$ Qaeda Central, with Droukdel declaring his loyalty to Osama bin Laden. ${ }^{45}$ The preliminary announcement of AQIM's establishment was made on September 11, 2006 (the fifth anniversary of the 9/11 attacks), and the actual merger announcement was issued in January 2007. ${ }^{46}$

Additionally, the emphasis of Al-Qaeda through the name change itself not only proposes a new portrayal of how this organization wants the public to see them as a stronger organization, but also has something to do with economic and political advantages they would get as an affiliate of AlQaeda. Also, their goals basis were slightly altered to a broader sense. The partnership gave AQIM's evolving identity a tactical and intellectual foundation, as well as a new goal of attacking Western targets outside of Algeria while remaining committed to overthrowing the Algerian government. ${ }^{47}$ The "ideological hybridization" that has occurred within jihadist circles as divisions between "revolutionary Islamist" groups focused on overthrowing local Muslim regimes and "global jihadist" organizations seeking to attack the West have eroded. ${ }^{48}$ In terms of operations, the group's Algerian base binds it to regional politics. The Islamist ideology of the organization calls for a theocracy in Algeria and the Sahel area, as well as Spain and Portugal as a part of their expansion. ${ }^{49}$

AQIM's affiliation with Al-Qaeda further demonstrates changes of methods. The merger of AQIM and al Qaeda core prompted a change away from traditional guerilla tactics and toward those adopted by al Qaeda and associated forces around the world. ${ }^{50}$ AQIM has altered its focus over time to softer targets that result in more losses from fewer operations. AQIM began using IEDs, suicide bombers, and coordinated operations shortly after the official partnership was formed. ${ }^{51}$ In 2007, 33 AQIM-linked assaults were identified in Algeria, 14 of which utilized at least one improvised explosive device (IED) and three of which used vehicle-borne improvised explosive devices (VBIEDs). ${ }^{52}$ Explosives were used more than half as much in 2007 as they were in 2006, but weapons were used far less. ${ }^{53}$ The quick transition in operations from weapons to suicide bombers and VBIEDs

\footnotetext{
${ }^{41}$ Ibid, 242.

${ }^{42}$ Ibid, 244.

${ }^{43}$ Ibid.

${ }^{44}$ Ibid

${ }^{45}$ Ibid

${ }^{46}$ Ibid.

${ }^{47}$ Ibid, William Thornberry and Jaclyn Levy, "Al Qaeda in the Islamic Maghreb," Transnational Threats Project: Homeland Security and Counterterrorism Program, 5-8.

${ }^{48}$ Ibid

${ }^{49}$ Ibid.

${ }^{50}$ Ibid.

${ }^{51}$ Ibid.

${ }^{52}$ Ibid.

${ }^{53}$ Ibid.
} 
showed a new trend intended at a larger number of people on a larger scale, as opposed to actions targeting government personnel specifically. ${ }^{54}$ The readiness of militants returning from Iraq to pass on newly gained fighting skills, including as IEDs and suicide bombs, to local fighters is believed to have assisted AQIM. ${ }^{55}$ In 2008, the trend of increasing violence persisted. Despite the fact that the total number of attacks fell, the attacks themselves were more violent. ${ }^{56}$

\section{b. Expansion of Influence through Identity Mobilization and Sectarianization}

As the Algerian government was alarmed and received international support in implementing the Algerian Counterterrorism Strategy, the existence of AQIM was threatened, forcing them to shift their operation into neighboring regions: the Mediterranean Coast and the Sahel. ${ }^{57}$ The current vacuum of power, gaping security flaw, and weak governments allows the AQIM to permeate within the existing societies, making the Sahel such an advantageous area to re-establish their power. ${ }^{58}$ Ever since, its battalions have formed tactical alliances and cultivated ties with local tribes and religious groups, realizing early on that success hinged on their ability to enlist the help of the locals. ${ }^{59}$ The jihadists can travel safely, change camps, and locate refuge and supplies in the desert thanks to these ties. $^{60}$

However, how exactly do the AQIM mobilize the identity of these groups and gain their support is what needs to be observed. There are various methods used by the AQIM to gain the trust of Sahelian Ethno-religious groups. First, since identity mobilization heavily depends on repetitive interactions to alter the groups' interests, the AQIM first aimed to penetrate to the social construction of these groups, which is done by manipulating their family ties. For example, Mokhtar Bel Mokhtar, one of AQIM's infamous veterans, spent a decade acquiring power in the Azawad desert settlements through intermarrying the women who belonged in affluent or highly respected tribes (he even married three different tribe women). ${ }^{61}$ Marriage aids in the formation and expansion of alliances, as well as the protection of jihadists married to tribe members, making it an antidote against defections. ${ }^{62}$ For the spouse of an AQIM terrorist, the mental and physical costs of departing the group are even greater, since she fears death or vengeance against her family. ${ }^{63}$

Additionally, as a result, AQIM thus has its own caches distributed throughout the huge Sahel area, acknowledged and left untouched by others, just as AQIM respects other caches. AQIM units equally expend a considerable effort in keeping good relations with any locals that are encountered during their travels. ${ }^{64}$ Coexistence with locals was the preferred strategy of AQIM's mobility, enabling them to frequently change camps to foil intelligence services that attempted to locate them. ${ }^{65}$

\footnotetext{
${ }^{54}$ Ibid.

${ }^{55}$ Ibid.

${ }^{56}$ Ibid.

${ }^{57}$ Ibid, William Thornberry and Jaclyn Levy, "Al Qaeda in the Islamic Maghreb," Transnational Threats Project: Homeland Security and Counterterrorism Program, 5-8.

${ }^{58}$ Dalia Ghanem, “Jihadism In The Sahel: Aqim's Strategic Maneuvers for Long-Term Regional Dominance," Malcolm H. Kerr: Carnegie Middle East Center, June 2017, https://carnegie-mec.org/2017/06/23/jihadism-in-sahel-aqim-s-strategicmaneuvers-for-long-term-regional-dominance-pub-71413.

${ }^{59}$ Ibid.

${ }^{60}$ Ibid.

${ }^{61}$ Ibid.

${ }^{62}$ Ibid.

${ }^{63}$ Ibid.

${ }^{64}$ Sergei Boeke, “Al Qaeda in the Islamic Maghreb: Terrorism, Insurgency, or Organized Crime?," Small Wars \& Insurgencies 27, no. 5 (May 2016): pp. 914-936, https://doi.org/10.1080/09592318.2016.1208280, 920-925., 920-925 ${ }^{65}$ Ibid.
} 
Travelling large distances, their modus operandi resemble the traditional nomadic rezzou, swift and brutal raids to destroy the enemy. ${ }^{66}$ AQIM's current freedom of movement stretches from Mauritania to Niger, and southern Algeria to Burkina Faso. ${ }^{67}$

AQIM's survival strategy in the Sahel is eerily similar to Al Qaeda Central's tactics in Afghanistan and Pakistan, where it was able to find refuge among the Pashtun tribes. Local and central governments' efficiency and competence as governments have dwindled in both of these sanctuaries (Afghanistan/Pakistan and the Sahel), while Al Qaeda and AQIM's have stayed stable or expanded ${ }^{68}$ In certain peripheral regions of the Sahel, AQIM is developing to function as a government unto itself, posing a threat to central administrations. ${ }^{69}$ It has the ability to demand taxes from local tribes, to administer justice on its own terms, to assault state representatives such as police and military officers, and to kidnap foreign visitors for ransom in the region, either alone or in concert with the Tuareg or Bérabiche tribes. ${ }^{70}$

The group has also met basic necessities by providing food, water, medicine, and gasoline to the community. ${ }^{71}$ Muggings, arms and people trafficking, money laundering, and, increasingly, the kidnapping of Western civilians for ransom or the release of prisoners are the main sources of AQIM's funding. ${ }^{72}$ The organization has made millions of Euros in ransom money from successful kidnappings of foreigners in Algeria, Mali, Mauritania, Chad, and Niger. ${ }^{73}$ An example is what happened back in 2003, where 32 German tourists were kidnapped and taken hostage for months when they were exploring the Sahara, and received an outstanding amount of ransom from the government. Per 2013, AQIM managed to gather approximately $\$ 100$ million, making it one of the biggest sources to fund this organization. ${ }^{74}$ Furthermore, the organization has also been involved in both legal and illegal trade within that area. For example, AQIM is heavily involved in the distribution of 'illegal' cigarettes that comes from Zerouate, Mauritania, as well as Kidal; and earned a considerable amount of money. ${ }^{75}$ Another source of significant funding includes drug trafficking. There have been reports that AQIM is getting involved in cocaine trafficking from West Africa to Europe through its well-established 0 -- defined as an Islamic unifying social bond, which has an organizational notion, implying that if one part of the ummah is harmed, then the other counterparts are too. Such creates a sense of responsibility to fight for the oppressed communities-- fuel them with willingness to fight for their 'oppressed brothers' worldwide; and at the same time push them to hate the western states (which contributes to the realization of Al-Qaeda's sectarianism agendas). ${ }^{76}$ As a result, many of the warriors were quite young, some even pre-adolescent. ${ }^{77}$ Even worse, hundreds of

\footnotetext{
${ }^{66}$ Ibid

${ }^{67}$ Ibid.

${ }^{68}$ Ibid, 247.

${ }^{69}$ Ibid.

${ }^{70}$ Ibid.

71 Ibid, William Thornberry and Jaclyn Levy, "Al Qaeda in the Islamic Maghreb," 3.

72 "Al-Qa'ida in the Lands of the Islamic Maghreb (AQIM)," Australian National Security (Attorney-General's Department, September 18, 2013), https://www.nationalsecurity.gov.au/Listedterroristorganisations/Pages/Al-Qaida-in-the-Lands-of-theIslamic-Maghreb.aspx.

${ }^{73}$ William K. Rashbaum, “U.S. Charges 3 Malians in Drug Plot,” The New York Times, December 18, 2009,

https://www.nytimes.com/2009/12/19/world/africa/19narco.html.

${ }^{74}$ Ibid, Javier E. David, “Al Qaeda’s Arm in North Africa Has Made around \$100 Million through Ransom and Drug Trading, Study Says."

${ }^{75}$ Morten Bøås and Liv Elin Torheim, "The Trouble in Mali-Corruption, Collusion, Resistance," Third World Quarterly

34, no. 7 (2013): pp. 1279-1292, https://doi.org/10.1080/01436597.2013.824647, 1270-1275.

${ }^{76}$ Ibid, Jean-Pierre Filiu, Al-Qaeda in the Islamic Maghreb: Algerian Challenge or Global Threat?, 8.

${ }^{77}$ Ibid, Sergei Boeke, “Al Qaeda in the Islamic Maghreb: Terrorism, Insurgency, or Organized Crime?,” 923-924.
} 
child soldiers were recruited during the jihadists' rule of northern Mali in 2012. ${ }^{78}$ The jihadists could easily recruit and press-gang children into service as the ruling authority. ${ }^{79}$

Once they had gained a strong basis of trust and support by the locals, AQIM began to exercise control. For instance, Droukdel underlined the need to gradually implement Sharia in a May 2012 audio address. He admitted that imposing all of Islam's precepts at once would be a mistake, but that "places of drugs, drunkenness, and immorality ought to be closed immediately." $80 \mathrm{He}$ also urged his AQIM "brothers" to provide security in the towns under their control, as well as the provision of critical facilities such as health care, water, and power. ${ }^{81}$ The Timbuktu letters, which are thought to have been sent in July, reaffirm his earlier message and recommend making concessions to the enemy or people. ${ }^{82}$ The goal of constructing these bridges was to make it apparent that our Mujahedin are no longer isolated in society, and to integrate with the various factions, including the big tribes and the main rebel movement and tribal chiefs, in order to avoid splits between the groupings and in society. ${ }^{83}$ This exemplifies the challenge of shifting from a terrorist to an insurgent tactic. ${ }^{84}$ The letter emphasizes moderation and caution, likening the Islamic enterprise in Azawad to a little child that needs to be fostered and helped to stand on its own two feet. ${ }^{85}$

Droukdel believed that the Sharia's introduction should not be rushed. Gradual evolution had to be applied in a religiously agnostic context. 'And our prior experience has shown that adopting Shariah in this manner without taking the surroundings into account will lead to people rejecting the faith, foment hostility toward the Mujahedin, and, as a result, our experiment will fail. ${ }^{186}$ The jihadists alienated huge sections of the people by criminalizing alcohol, smoking, and the music and dance that are so important to local culture, as well as imposing draconian hudud punishments. ${ }^{87}$ In his letter, Droukdel also chastised Ansar Dine for destroying the shrines in Timbuktu, which was highly unpopular. ${ }^{88}$ In 2013, Operation Serval proved him correct, as joyful people greeted the French as liberators. ${ }^{89}$

\section{Conclusion}

In conclusion, the usage of both ethnic and religious identities, as well as addressing the gap states are unable to fulfill actually works in obtaining popular support in a region. Internally, strategic identity mobilization had been seen since the GSPC under Hattab's leadership utilized the hatred of devout Muslim members to establish a new strong organization and separate itself from GIA. However, how the power transition from Hattab to Droukdel changed the objective of this organization also implies that the identity of a group can be altered to fulfill its leader's objectives, highlighting the notion brought up by Vali Nasr, stating that identity mobilization is a result of political leaders' projection of power. Externally, AQIM as a terrorist group has managed to gain popular support of ethno-religious 
groups by mobilizing their identity to fit onto the organizations' political objectives. By implementing various methods --such as developing intermarriage ties; giving economic incentives; and utilizing the area's vacuum of power, gaping security flaw, and weak governments; and manifesting sectarianists agenda to attract recruits-- AQIM build strong foundations as one of the most influential non-state actors that operates within the Sahel Region.

\section{References:}

Al Jazeera. "The Sahel: Key Things to Know as Security Crisis Spirals." Environment | Al Jazeera. A1 Jazeera, February 27, 2020. https://www.aljazeera.com/features/2020/2/27/the-sahel-keythings-to-know-as-security-crisis-spirals.

"Al-Qa'ida in the Lands of the Islamic Maghreb (AQIM)." Australian National Security. AttorneyGeneral's Department, September 2013. https://www.nationalsecurity.gov.au/Listedterroristorganisations/Pages/Al-Qaida-in-the-Landsof-the-Islamic-Maghreb.aspx.

Bergensen, Albert J., and Omar Lizardo. "International Terrorism and the World-System." Sociological Theory 22, no. 1 (2004): 38-52.

Bøås, Morten, and Liv Elin Torheim. "The Trouble in Mali-Corruption, Collusion, Resistance." $\begin{array}{llllll}\text { Third World } & \text { Quarterly } 34, & \text { no. } & 7 & \text { (2013): }\end{array}$ https://doi.org/10.1080/01436597.2013.824647.

Boeke, Sergei. "Al Qaeda in the Islamic Maghreb: Terrorism, Insurgency, or Organized Crime?" Small Wars \&amp; Insurgencies 27, no. 5 (2016): 914-36. https://doi.org/10.1080/09592318.2016.1208280.

David, Javier E. “Al Qaeda's Arm in North Africa Has Made around \$100 Million through Ransom and Drug Trading, Study Says." CNBC. CNBC, December 7, 2017. https://www.cnbc.com/2017/12/06/al-qaedas-arm-in-north-africa-has-made-100-milliondollars-via-ransom-drug-trade.html.

Filiu, Jean-Pierre. Al-Qaeda in the Islamic Maghreb: Algerian Challenge or Global Threat? 104. Vol. 104. Washington, DC: Carnegie Endowment for International Peace, 2009.

Ghanem, Dalia. “Jihadism In The Sahel: Aqim's Strategic Maneuvers for Long-Term Regional Dominance." Malcolm H. Kerr: Carnegie Middle East Center, June 2017. https://carnegiemec.org/2017/06/23/jihadism-in-sahel-aqim-s-strategic-maneuvers-for-long-term-regionaldominance-pub-71413.

Griffith, Nathan. "Mali-Al-Qaida's Sahara Playbook ." The Associated Press. Accessed September 23, 2021. https://www.openbriefing.org/docs/aqsaharaplaybook.pdf. 
175 Adzraa Shaffa Andira | Sectarianization, Identity, and How Terrorism Prevails: The Case of Al-Qaeda in the Islamic Maghreb (AQIM) in the Sahel Region of Africa

Hashemi, Nader, and Danny Postel. "Sectarianization: Mapping the New Politics of the Middle East." The Review of Faith \& International Affairs 15, no. 3 (2017): 1-13. https://doi.org/10.1080/15570274.2017.1354462.

Larémont, Ricardo René. "Al Qaeda in the Islamic Maghreb: Terrorism and Counterterrorism in the Sahel.” African Security 4, no. 4 (2011): 242-68. https://doi.org/10.1080/19392206.2011.628630.

"Mapping Militants Profile Index." Center for International Security and Cooperation (CISAC). Stanford University: Freeman Spogli Institute fro International Studies, 2016. https://cisac.fsi.stanford.edu/mappingmilitants/profiles.

Nasr, Vali R. "International Politics, Domestic Imperatives, and Identity Mobilization: Sectarianism in Pakistan, 1979-1998." Comparative Politics, 171, 32, no. 2 (2000): 171-75. https://doi.org/10.2307/422396.

Rashbaum, William K. "U.S. Charges 3 Malians in Drug Plot.” The New York Times, December 18, 2009. https://www.nytimes.com/2009/12/19/world/africa/19narco.html.

Ritchie, Hannah, Joe Hasell, Cameron Appel, and Max Roser. "Terrorism." Our World in Data, July 28, 2013. https://ourworldindata.org/terrorism.

Telhami, Shibley, and Michael N. Barnett. Identity and Foreign Policy in the Middle East. Ithaca, NY: Cornell University Press, 2002.

"Terrorism: Number of Attacks Worldwide 2019." Statista, June 28, 2021. https://www.statista.com/statistics/202864/number-of-terrorist-attacks-worldwide/.

"The Sahel: Key Things to Know as Security Crisis Spirals." Al Jazeera. Al Jazeera, February 27, 2020. https://www.aljazeera.com/features/2020/2/27/the-sahel-key-things-to-know-as-securitycrisis-spirals.

"The Sahel: Land of Opportunities | Africa Renewal." United Nations. United Nations. Accessed July 5, 2021. https://www.un.org/africarenewal/sahel.

Shahbahrami, Daryoush. "Identity and Power in International Relations." International Journal of Humanities and Cultural Studies, May 2016, 2434-46.

"Terrorist Attacks by Region." Our World in Data. Accessed July 5, 2021. https://ourworldindata.org/grapher/terrorist-attacks-by-region.

Thornberry, William, and Jaclyn Levy. "Al Qaeda in the Islamic Maghreb." Transnational Threats Project: Homeland Security and Counterterrorism Program. Center for Strategic and International Studies, September 2011. https://www.csis.org/analysis/al-qaeda-islamicmaghreb. 
176 Adzraa Shaffa Andira | Sectarianization, Identity, and How Terrorism Prevails: The Case of Al-Qaeda in the Islamic Maghreb (AQIM) in the Sahel Region of Africa

Wing, Susanna D. "French Intervention in Mali: Strategic Alliances, Long-Term Regional Presence?" Small Wars \&amp; Insurgencies 27, no. $1 \quad$ (2016): 59-80. https://doi.org/10.1080/09592318.2016.1123433.

Zehfuss, Maja. "Constructivism and Identity: A Dangerous Liaison." European Journal of International Relations 7, no. 315 (2001): 93. https://doi.org/DOI: 10.1177/1354066101007003002. 